\title{
РАСПРЕДЕЛЕНИЕ СаО И МgО В ВЕНЛОКСКИХ ОТЛОЖЕНИЯХ ПРИБАЛТИКИ
}

Изучение фациальных условий венлокского века заставило нас обратить вниманис на геохимию пород, в первую очередь, на содержание карбонатов. Породы венлока Прибалтики, как правило, весьма глинистые. Преобладающая часть их представлена мергелями, домеритами (названия и классификация пород по Vingisaar и др., 1965) и глинами, в меньшей степени известняками и доломитами (рис. 1, 2). По внешности мергели и домериты массивные серые, а также синевато- или зеленовато-серые, местами тонкослоистые породы; содержат в варьирующем количестве органогенный детрит. Глины серые, зеленоватые с пиритизированными ходами илоедов. Известняки сложены в основном из тонкокристаллического кальцита с примесыо кальцитового органогенного детрита. В небольшом количестве встречаются биогермовые известняки (Кальо и др., 1970). Часть известняков охвачена вторичной доломитизацией различной степени вплоть до чистых доломитов. Доломиты серые, кавернозные, местами массивные, варьируются от тонко- до крупнокристаллических.

Рис. 1. Схема распространения венлокских отложений и расположения изученных скважин.

I - зона известняков, доломитов, мергелей и домеритов; II - зона мергелей и домеритов; III - зона глин.

Скважнны: 1 - Куревере, 2 - Мустъяла, 3 - Нурме, 4 - Кирикукюла, 5 - Пярну, 6 - Икла, 7 - Сакла, 8 - Кингисceпra, 9 - Кипи, 10 - Oxecaаpe, 11 Колка, 12 - Талси, 13 - Нитауре, 14 Аташиене, 15 - Кроньауце, 16 - Приекуле, 17 - Бернаты, 18 - Паровея, $19-$ Кункояй, 20 - Плунге, $21-$ Укмерге, 22 - Лапес, 23 - Вирбалис, 24 - Калвария, $25-$ Кашино, 26 - Вильнюс. 1 - граница распространения венлокских отложений, 2 - граница распространения полных мощностей, 3 - гранищы зон.

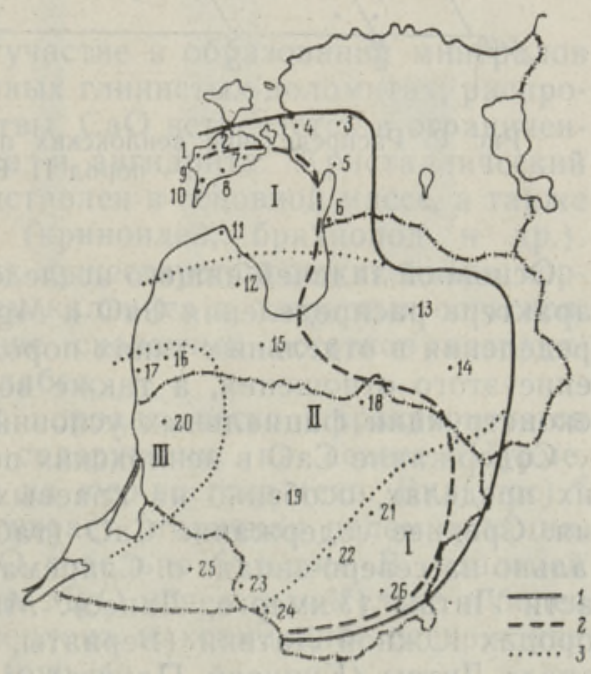

Разнообразие типов пород в венлокском ярусе и их неоднократное чередование обусловливают сложное распределение $\mathrm{CaO}$ и $\mathrm{MgO}$. Для выявления химического состава отложений и особенностей распределения $\mathrm{CaO}$ и $\mathrm{MgO}$ в венлоке нами исследовалось 500 образцов из 25 скважин. Определяемые $\mathrm{CaO}$ и $\mathrm{MgO}$ выделялись из растворимой части пород 
в лаборатории Института геологии АН ЭССР под руководством Л. Сяга ускоренным методом трилонометрического титрования (метод трилон Б).

Для характеристики содержаний $\mathrm{CaO}$ и $\mathrm{MgO}$ в отдельных типах пород и разрезах были вычислены их средние значения и стандартные отклонения. При этом в разрезах скважин учитывалась мощность соответствующего слоя, содержащего постоянное количество $\mathrm{CaO}$ и $\mathrm{MgO}$.

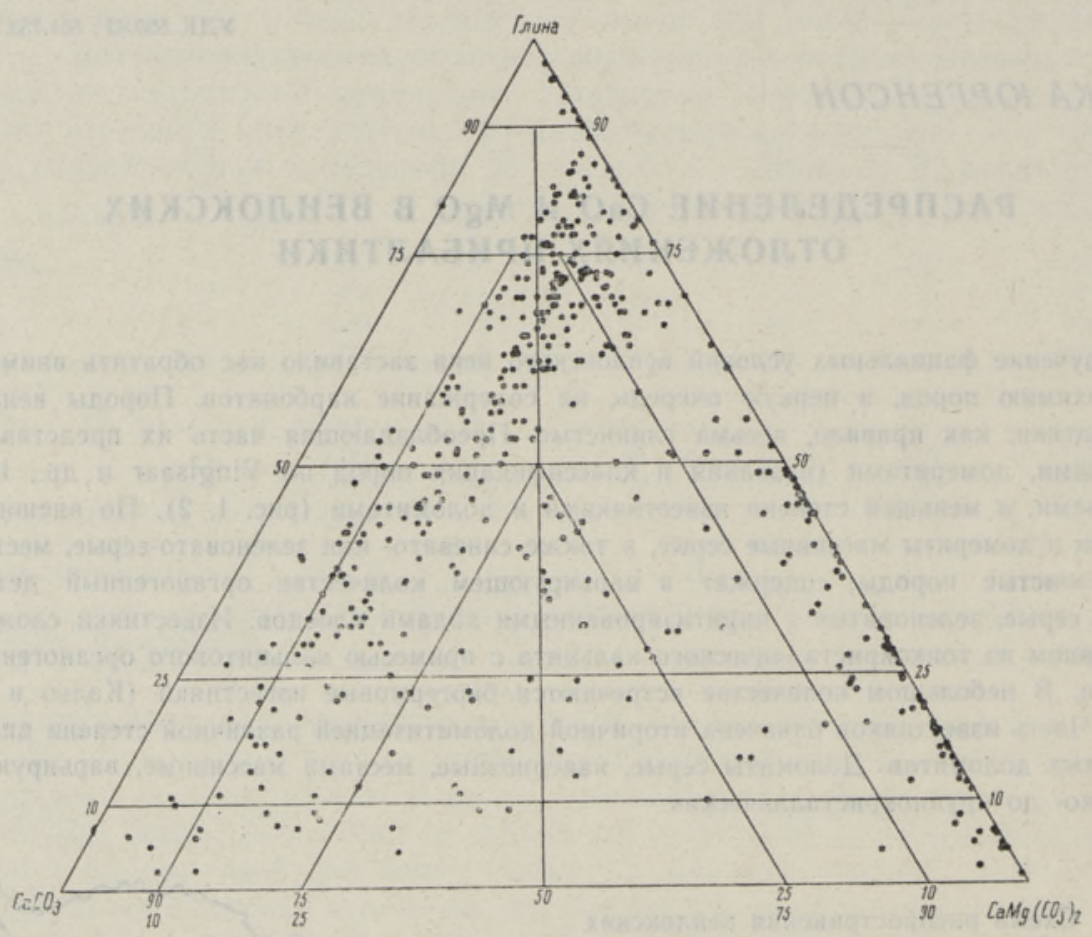

Рис. 2. Распределение венлокских пород по классификации карбонатных пород П. Вингисаара и др. (1965).

Основной задачей нашего исследования было установление 1) общего характера распределения $\mathrm{CaO}$ и $\mathrm{MgO}$ в отложениях венлока; 2) их распределения в отдельных типах пород; 3) их отношения $(\mathrm{Ca} / \mathrm{Mg})$ и изменение этого отношения, а также возможности его использования при реконструкции фациальных условий.

Содержание $\mathrm{CaO}$ в венлокских породах колеблется в довольно широких пределах, особенно на краевых участках бассейна осадконакопления. Среднее содержание $\mathrm{CaO}$ (табл. 1) в венлокских породах максимально на северо-западе о. Сааремаа (Куревере, Кипи) и в центральной части Литвы (Укмерге, Лапес). Минимальное содержание отмечено в породах Южной Латвии (Бернаты, Приекуле, Кроньауце, Нитауре), на западе Литвы (Кункояй, Плунге), и в Калининградской области (Кашино). Распределение $\mathrm{CaO}$ по вертикальному разрезу венлока довольно равномерное (рис. 3). Только в более северных разрезах (Колка, Талси и др.) наблюдается увеличение содержания $\mathrm{CaO}$ в его верхних слоях (яагарахуский горизонт). Минимальное содержание связано в большинстве разрезов со средней частью яруса. 
таблица 1

Содержание $\mathrm{CaO}, \mathrm{MgO}$ и нерастворимого остатка в венлокских отложениях Прибалтики

\begin{tabular}{|c|c|c|c|c|c|c|c|}
\hline \multirow{2}{*}{$\begin{array}{c}\text { № } \\
\text { скважин * }\end{array}$} & \multirow{2}{*}{$n$} & \multicolumn{2}{|c|}{$\mathrm{CaO}$} & \multicolumn{2}{|c|}{$\mathrm{MgO}$} & \multicolumn{2}{|c|}{ Нераствор. остаток } \\
\hline & & $\bar{x}$ & $S$ & $\vec{x}$ & $S$ & $\vec{x}$ & $S$ \\
\hline $\begin{array}{r}1 \\
2 \\
3 \\
4 \\
5 \\
6 \\
7 \\
8 \\
9 \\
10 \\
11 \\
12 \\
13 \\
14 \\
15 \\
16 \\
17 \\
18 \\
19 \\
20 \\
21 \\
22 \\
23 \\
24 \\
25\end{array}$ & $\begin{array}{r}16 \\
17 \\
10 \\
8 \\
34 \\
13 \\
20 \\
20 \\
25 \\
41 \\
30 \\
10 \\
6 \\
13 \\
16 \\
15 \\
14 \\
20 \\
13 \\
10 \\
10 \\
14 \\
12 \\
25 \\
15\end{array}$ & $\begin{array}{r}37,8 \\
24,0 \\
13,2 \\
15,3 \\
21,0 \\
15,3 \\
21,6 \\
36,9 \\
27,3 \\
27,0 \\
16,2 \\
11,2 \\
3,7 \\
16,4 \\
12,1 \\
10,5 \\
6,6 \\
17,0 \\
12,3 \\
8,4 \\
25,6 \\
24,6 \\
14,0 \\
19,3 \\
12,0\end{array}$ & $\begin{array}{r}2,6 \\
6,9 \\
7,1 \\
4,1 \\
3,4 \\
4,1 \\
6,8 \\
8,2 \\
7,4 \\
10,4 \\
8,8 \\
8,8 \\
3,3 \\
6,0 \\
8,3 \\
9,7 \\
1,6 \\
8,2 \\
2,2 \\
1,4 \\
10,6 \\
11,2 \\
8,4 \\
9,1 \\
10,2\end{array}$ & $\begin{array}{r}8,4 \\
11,8 \\
8,4 \\
10,6 \\
10,1 \\
8,0 \\
15,5 \\
8,9 \\
10,6 \\
3,4 \\
6,5 \\
4,4 \\
2,7 \\
5,8 \\
4,0 \\
2,9 \\
4,4 \\
5,8 \\
3,6 \\
2,8 \\
4,6 \\
3,0 \\
2,9 \\
4,0 \\
3,2\end{array}$ & $\begin{array}{l}5,9 \\
5,7 \\
2,3 \\
2,8 \\
3,7 \\
4,5 \\
5,0 \\
4,1 \\
6,7 \\
2,3 \\
6,0 \\
0,3 \\
1,8 \\
2,1 \\
1,0 \\
1,0 \\
1,2 \\
2,8 \\
0,1 \\
0,2 \\
3,3 \\
0,6 \\
1,1 \\
4,4 \\
0,5\end{array}$ & $\begin{array}{l}16,0 \\
32,1 \\
58,0 \\
50,2 \\
41,4 \\
54,0 \\
29,9 \\
15,5 \\
30,0 \\
45,1 \\
57,4 \\
74,0 \\
88,1 \\
60,4 \\
70,6 \\
75,2 \\
78,0 \\
57,9 \\
69,3 \\
80,0 \\
50,1 \\
50,0 \\
69,0 \\
56,7 \\
71,4\end{array}$ & $\begin{array}{r}6,6 \\
11,2 \\
4,9 \\
12,8 \\
16,6 \\
15,3 \\
22,7 \\
8,8 \\
18,7 \\
18,4 \\
24,2 \\
16,0 \\
10,8 \\
12,1 \\
15,0 \\
10,6 \\
4,8 \\
15,0 \\
4,5 \\
4,8 \\
16,6 \\
19,7 \\
13,4 \\
16,9 \\
17,6\end{array}$ \\
\hline
\end{tabular}

* Названия скважин см. на рис. 1. Обозн ачения: $n-$ число изученных образцов; $\bar{x}-$ средне-арифметическое содержание; $S$ - стандартное отклонение.

$\mathrm{CaO}$ принимает главным образом участие в образовании минералов кальцита и доломита. Только в первичных глинистых доломитах, распространенных в юго-восточной части Литвы, СаO встречается в ограниченном количестве также в составе гипса и ангидрита. Кристаллический кальцит (диам. больше 0,005 мм) представлен в основной массе, а также в скелетах различных организмов (криноидей, брахиопод и др.). В известняках и известковых мергелях существует положительная корреляционная связь между содержанием кальцита и скелетных остатков. В глинистых мергелях, где содержание скелетных остатков незначительно, эта связь выражена гораздо слабее.

Распределение $\mathrm{MgO}$ в венлокских породах четко характеризуется двумя районами его максимального содержания: на севере (Нурме, Кирикукюла, Сакла, Пярну, Икла) и на юго-востоке (скв. Вильнюс).* В обоих районах значительную роль ипрает вторичная доломитизация, поэтому колебания в содержании $\mathrm{MgO}$ довольно большие. В остальной части исследуемого региона содержание $\mathrm{MgO}$ менее значительно и более однородно. В вертикальном разрезе венлока максимальное содержание MgO связано с его верхними слоями (рис. 4).

$\mathrm{MgO}$ является главным компонентом доломита, в меньшей мере, возможно, и анкерита. Присутствие магнезита в венлоке Прибалтики пока нами не установлено. Диаметр кристаллов доломита варьируется в боль-

* Ввиду недостатка данных скв. Вильнюс в табл. 1 не включена. 
ших пределах: от крупно- до мелкокристаллических $(0,05-0,5$ мм) в доломитах, от микро-до тонкокристаллических $(0,01-0,05$ мм) в домеритах. Часто встречаются идиоморфные кристаллы.
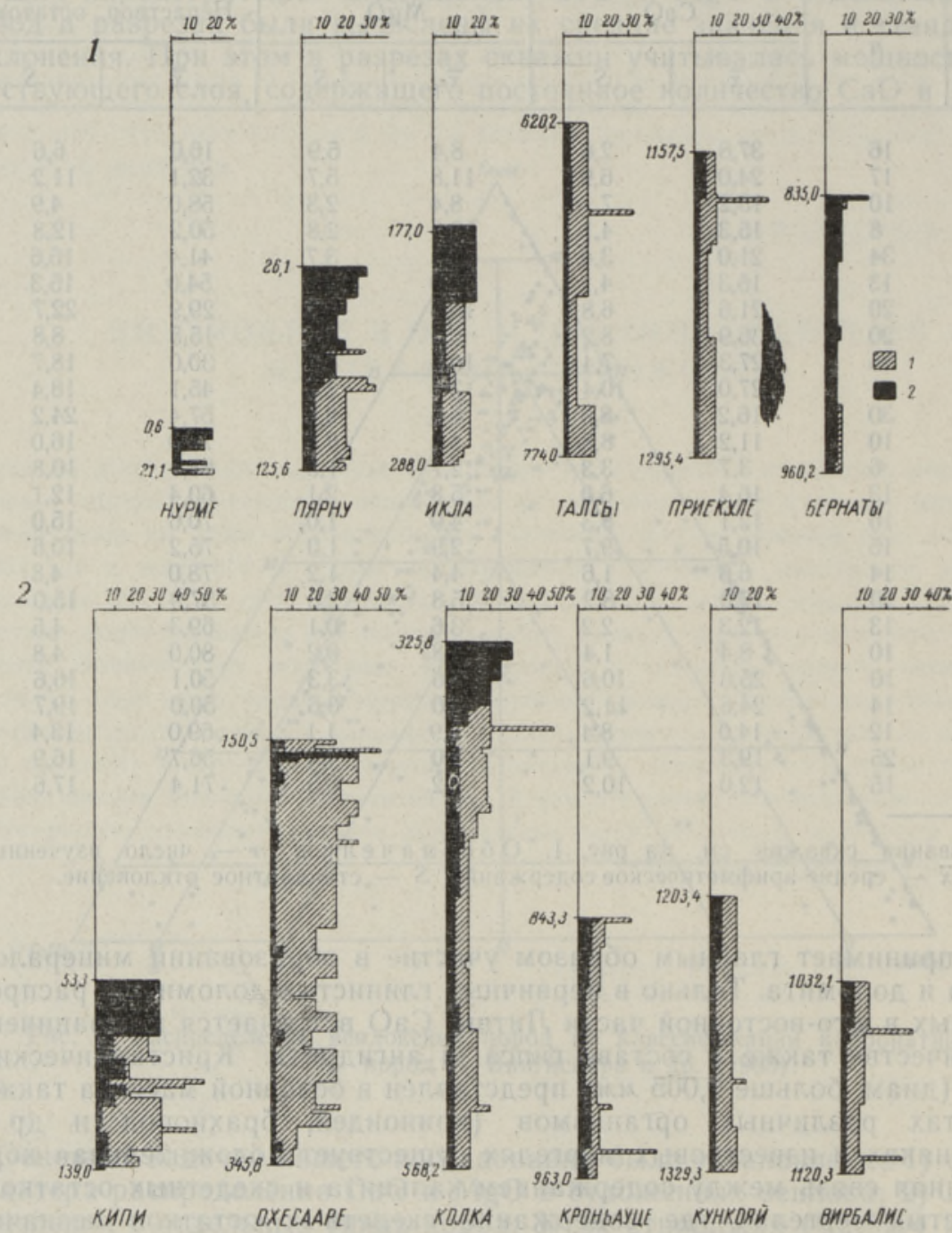

Рис. 3. Распределение содержания $\mathrm{CaO}$ в разрезах венлока.

1 - общее содержание $\mathrm{CaO}, 2-\mathrm{CaO}$, входящий в состав $\mathrm{CaMg}\left(\mathrm{CO}_{3}\right)_{2}$.

При исследовании распределения $\mathrm{CaO}$ и $\mathrm{MgO}$ в отдельных типах пород венлока в первую очередь учитывалась классификация по содержанию нерастворимого остатка (терригенного материала). На полигонах распределения видно (рис. 5), что частота встречаемости СаO и $\mathrm{MgO}$ в породах с содержанием нерастворимого остатка от 0 до $10 \%$, имеет два максимума. Первый максимум (А) у СаO соответствует, по-видимому, чистым доломитам, а второй (Б) известнякам. В распределении $\mathrm{MgO}$ первый максимум (A) соответствует известковым породам, а второй (Б) доломитовым. Оба максимума в распределении MgO сохраняются и при содержании нерастворимого остатка $10-25 \%$ и $25-50 \%$, 
а в породах с содержанием нерастворимого остатка больше $50 \%$ остается один максимум. В табл. 2 приведены соответствующие отдельным типам пород средние содержания и стандартные отклонения СаO и MgO. Сле-
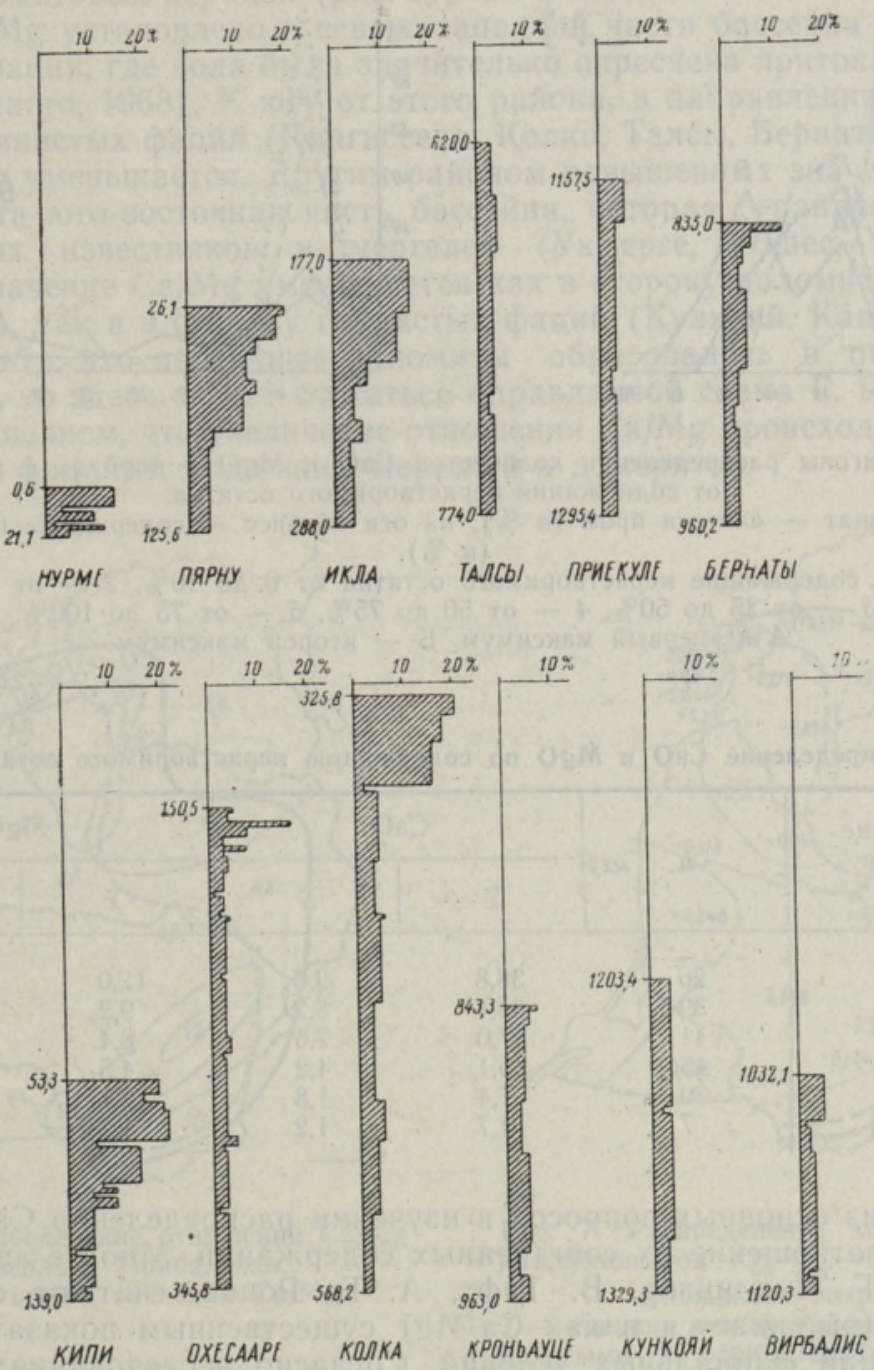

Рис. 4. Распределение содержания $\mathrm{MgO}$ в разрезах венлока.

дует отметить, что уменьшение среднего содержания $\mathrm{CaO}$ происходит быстрее в породах с количеством нерастворимого остатка выше $50 \%$, тогда как уменьшение $\mathrm{MgO}$ с возрастанием количества нерастворимого остатка происходит более плавно. Исследование отношения содержаний $\mathrm{CaO}$ и нерастворимого остатка показало, что связь между ними является обратно пропорциональной, причем сила связи возрастает тем более, чем глинистее породы. Такой же характер имеет в большинстве случаев и связь между $\mathrm{MgO}$ и нерастворимым остатком. Только здесь не обнаружено закономерного изменения силы связи. При этом надо отметить, что отношение между $\mathrm{MgO}$ и нерастворимым остатком пока еще недостаточно изучено и требует дальнейшего уточнения. 


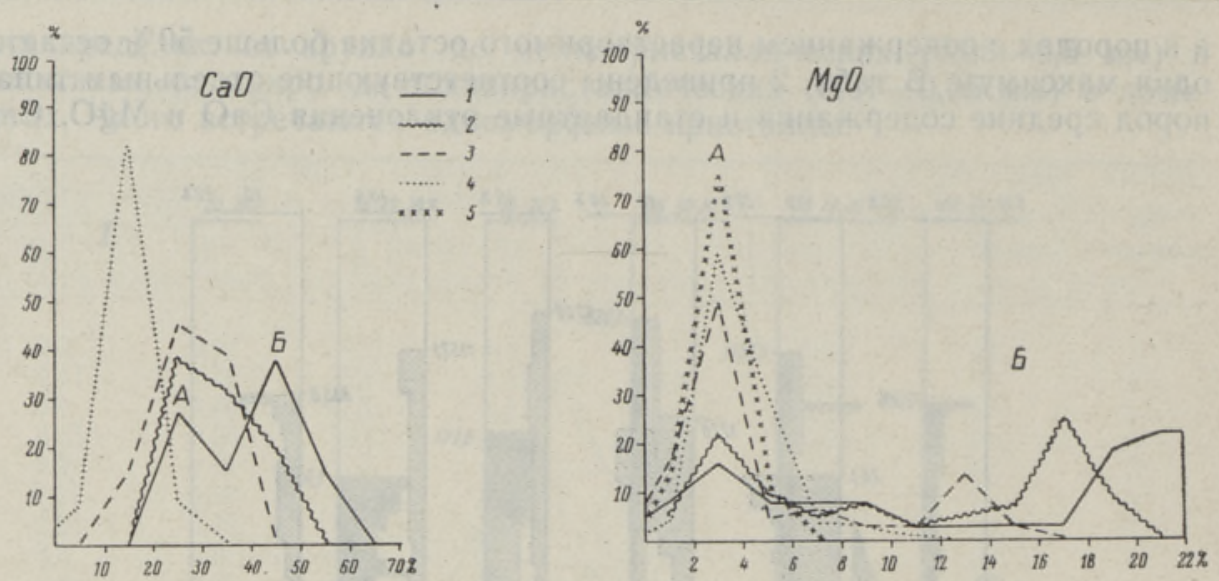

Рис. 5. Полигоны распределения количества $\mathrm{CaO}$ и $\mathrm{MgO}$ в породах в зависимости от содержания нерастворимого остатка.

На оси ординат - частота проб (в \%), на оси абсцисс - содержание $\mathrm{CaO}$ и $\mathrm{MgO}$ (в \%).

1 - породы, содержащие нерастворимого остатка от 0 до $10 \%, 2$ - от 10 до $25 \%$, 3 - от 25 до $50 \%, 4$ - от 50 до $75 \%, 5$ - от 75 до $100 \%$.

А - первый максимум, Б - второй максимум.

Таблица 2

Распределение $\mathrm{CaO}$ и $\mathrm{MgO}$ по содержанию нерастворимого остатка

\begin{tabular}{c|c|c|c|c|c}
\hline \multirow{2}{*}{$\begin{array}{c}\text { Содержание } \\
\text { нераствор. }\end{array}$} & \multirow{2}{*}{$\begin{array}{c}\text { CaO } \\
\text { остатка, \% }\end{array}$} & & $\bar{x}$ & $S$ & \multicolumn{2}{|c}{$\mathrm{MgO}$} \\
\cline { 3 - 6 } & & & & $\bar{x}$ & $S$ \\
\hline $0-10$ & 26 & 38,8 & 9,6 & 12,0 & 8,1 \\
$10-25$ & 39 & 35,1 & 8,2 & 9,2 & 6,3 \\
$25-50$ & 41 & 27,0 & 7,6 & 6,4 & 4,6 \\
$50-75$ & 45 & 15,1 & 4,2 & 4,5 & 1,8 \\
$75-90$ & 30 & 7,4 & 1,8 & 3,1 & 0,7 \\
$90-100$ & 7 & 1,7 & 1,2 & 1,5 & 0,6
\end{tabular}

Одним из основных вопросов в изучении распределения $\mathrm{CaO}$ и $\mathrm{MgO}$ является соотношение их собственных содержаний. Многие авторы, как например Г. Чиллингар, В. Тафт, А. Б. Ронов, считают отношение $\mathrm{CaO} / \mathrm{MgO}$ (выражается и как $\mathrm{Ca} / \mathrm{Mg}$ ) существенным показателем при интерпретации фациальных условий. Согласно исследованиям Г. Чиллингара (Chillingar, 1960), отношение $\mathrm{Ca} / \mathrm{Mg}$ в осадках возрастает по мере удаления от берега. Наибольшее влияние при этом имеет соленость воды. Установлено (Ingerson, 1962), что $\mathrm{Ca} / \mathrm{Mg}$ уменьшается с ростом солености воды. В зависимости от условий конкретного бассейна осадконакопления здесь могут быть разные отклонения от общего правила. Этим обстоятельством, вероятно, объясняются и противоречащие выводам Г. Чиллингара результаты А. Б. Ронова (1956), по которым в палеозойских карбонатных породах Русской платформы отношение $\mathrm{Ca} / \mathrm{Mg}$ по мере удаления от берега бывшего бассейна уменьшается. При всех палеофациальных интерпретациях следует также учитывать, что результаты будут тем правдоподобнее, чем меньше вторичных изменений претерпели отложения.

Исследованные нами венлокские отложения Прибалтики являются только местами типично карбонатными, большей же частью они пред- 
ставлены терригенно-карбонатными и глинистыми отложениями, образовавшимися в разных фациальных зонах. Осложняющим фактором является и вторичная доломитизация. Отношение $\mathrm{Ca} / \mathrm{Mg}$ незначительно как в доломитовых породах (рис. 6), так и в глинах. Максимальное значение $\mathrm{Ca} / \mathrm{Mg}$ установлено в северо-западной части бассейна в пределах рифовой фации, где вода была значительно опреснена притоками с материка (Эйнасто, 1968). К югу от этого района, в направлении открытого моря и глинистых фаций (Кингиссепа, Колка, Талсы, Бернаты), отношение $\mathrm{Ca} / \mathrm{Mg}$ уменьшается. Другим районом повышенных значений $\mathrm{Ca} / \mathrm{Mg}$ является та юго-восточная часть бассейна, которая ограничена фацией комковатых известняков и мергелей (Укмерге, Лапес, Вирбалис). Отсюда значение $\mathrm{Ca} / \mathrm{Mg}$ уменьшается как в сторону доломитовых пород (Вильнюс), так и в сторону глинистых фаций (Кункояй, Кашино). Если предполагать, что первичные доломиты образовались в окрестностях Вильнюса, то здесь может считаться оправданной схема Г. Чиллингара, с тем уточнением, что увеличение отношения $\mathrm{Ca} / \mathrm{Mg}$ происходит до более глинистых фаций, т. е. до зоны мергелей и домеритов.

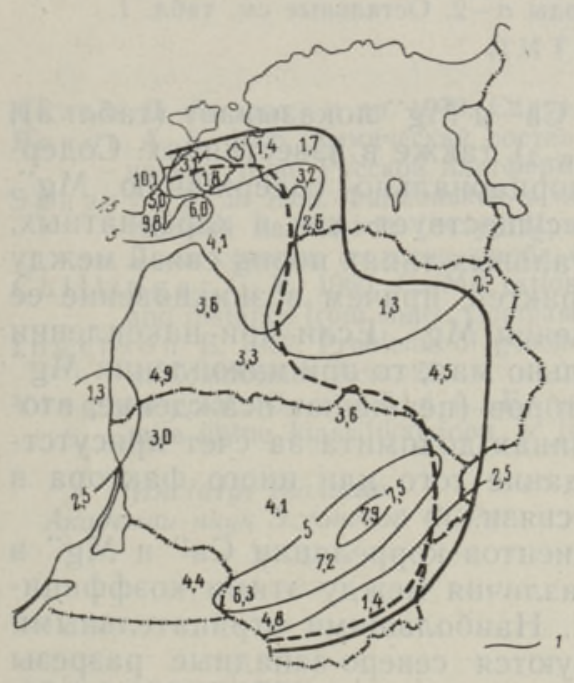

Рис. 6. Распределение отношений $\mathrm{Ca} / \mathrm{Mg}$ в венлоке Прибалтики.

1 - изолинии значений $\mathrm{Ca} / \mathrm{Mg}$.

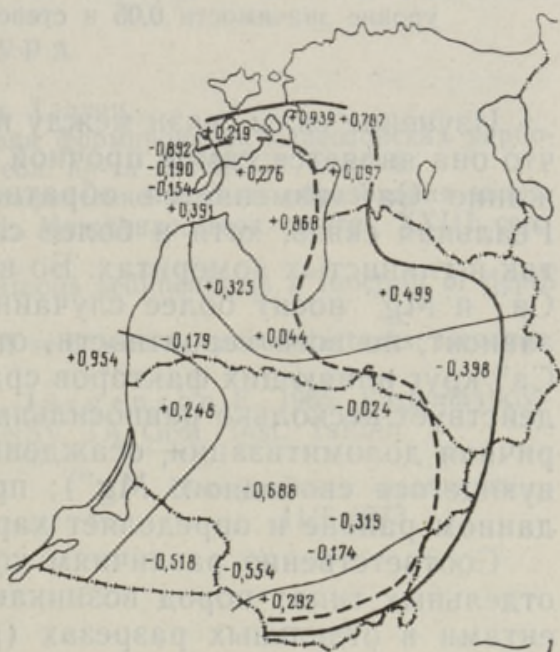

Рис. 7. Распределение корреляционных коэффициентов $r_{\mathrm{Ca}}{ }_{\mathrm{Mg}}$. исследованных венлокских разрезов.

1 - граница между районами с положительными и отрицательными корреляциями.

Для лучшего понимания поведения величины $\mathrm{Ca} / \mathrm{Mg}$ в венлокских отложениях были определены ее средние значения в отдельных типах пород, а также коэффициенты корреляции между ионами $\mathrm{Ca}$ “ и $\mathrm{Mg}^{*}$. (Чтобы избежать возможных ошибок в корреляции между процентными величинами, содержание $\mathrm{CaO}$ и $\mathrm{MgO}$ было пересчитано на Са“ и $\left.\mathrm{Mg}^{\prime \prime}\right)$.

Отношение $\mathrm{Ca} / \mathrm{Mg}$ имеет самое высокое значение в известняках. В глинистых известняках и карбонатных мергелях оно почти одинаково, но меньше, чем в известняках. В глинистых мергелях оно уже в три раза меньше, чем в чистых известняках. В доломитовых породах величина $\mathrm{Ca} / \mathrm{Mg}$ более стабильна и колеблется около значения 2. В глинистых домеритах эти значения слегка увеличиваются. Самое низкое значение $\mathrm{Ca} / \mathrm{Mg}$ установлено в чистых глинах. 
Средне-арифметическое отношение $\mathrm{Ca} / \mathrm{Mg}$ и коэффициент корреляции между $\mathrm{Ca}^{*}$ и $\mathrm{Mg}^{*}$ в отдельных типах пород

\begin{tabular}{|c|c|c|c|c|c|}
\hline Типы пород & $n$ & $\bar{x}$ & $r_{\mathrm{Ca}}{ }^{\mathrm{M}} \mathrm{M} "$ & $t$ & $t_{q, n-2}$ \\
\hline $\begin{array}{l}\text { Известняк } \\
\text { Глинистый известняк } \\
\text { Карбонатңый мергель } \\
\text { Глинистый мергель } \\
\text { Доломит } \\
\text { Глинистый доломит } \\
\text { Карбонатный домерит } \\
\text { Глинистый домерит } \\
\text { Карбонатная глина } \\
\text { Глина }\end{array}$ & $\begin{array}{r}15 \\
39 \\
24 \\
17 \\
18 \\
16 \\
23 \\
22 \\
30 \\
7\end{array}$ & $\begin{array}{r}17,6 \\
11,7 \\
11,3 \\
5,7 \\
1,6 \\
1,7 \\
1,9 \\
2,8 \\
2,5 \\
1,2\end{array}$ & $\begin{array}{l}-0,914 \\
-0,810 \\
-0,091 \\
+0,334 \\
-0,182 \\
+0,276 \\
-0,450 \\
+0,131 \\
-0,206 \\
+0,632\end{array}$ & $\begin{array}{l}8,1 \\
8,3 \\
0,4 \\
1,4 \\
0,7 \\
1,1 \\
2,3 \\
2,0 \\
1,1 \\
1,8\end{array}$ & $\begin{array}{l}2,2 \\
2,0 \\
2,1 \\
2,1 \\
2,1 \\
2,2 \\
2,1 \\
2,1 \\
2,1 \\
2,4\end{array}$ \\
\hline
\end{tabular}

О бозн ачения: $t-$ критерий Стъюдента; $t q, n-2-$ допустимое значение $t$ при уровне значимости 0.05 и степени свободы $n-2$. Остальные см. табл. 1 .

Изучение силы связи между ионами Са“" и $\mathrm{Mg}$ “ показывает (табл. 3), что она является самой прочной $\left(t>t_{q, n-2}\right)$ также в известняках. Содержание Са" изменяется обратно пропорционально содержанию $\mathrm{Mg}$ “. Реальная связь, хотя и более слабая, существует как в карбонатных, так и глинистых домеритах. Во всех остальных типах пород связь между Сa" и $\mathrm{Mg}$ " носит более случайный характер, причем возникновение ее зависит, по всей вероятности, от поведения $\mathrm{Mg}$ ". Если при накоплении $\mathrm{Ca}$ “ круг влияющих факторов сравнительно мал, то при накоплении $\mathrm{Mg}^{*}$ действует несколько равносильных факторов (первичное осаждение, вторичная доломитизация, осаждение в глинах доломита за счет присутствующегося свободного $\mathrm{Mg}$ "); преобладание того или иного фактора в данном районе и определяет характер связи.

Соответственно различиям коэффициентов корреляции Са“" и $\mathrm{Mg}^{\prime}$ в отдельных типах пород возникают и различия между этими коэффициентами в отдельных разрезах (рис. 7). Наибольшими отрицательными значениями коэффициентов характеризуются северо-западные разрезы (Куревере), где распространены чистые известняки. Самая сильная положительная корреляция соответствует местам, где больше распространены глинистые доломитовые породы и глины (Кирикукюла, Икла, Бернаты). Из распределения положительных и отрицательных коэффициентов следует, что в исследуемых породах в большинстве случаев увеличение содержания Са“ сопровождается увеличением содержания Mg“.

Подытоживая изложенные выше результаты исследований, можно сделать некоторые выводы об условиях накопления кальция и магния в венлокском веке.

1. Накопление кальция в виде кальцита было более интенсивным в начале и конце венлокского века. Основная часть его образовалась в виде тонкозернистого ила. Только в конце века образовалось сравнительно больше крупнозернистых биогенных отложений, особенно на краевых участках бассейна.

2. Преобладающая часть магния связана со вторичными доломитами, распространенными в верхней части венлока в восточных районах Прибалтики. Первичное осаждение доломитов происходило лишь кратковременно и на очень ограниченных участках с повышенной соленостью воды. В глинистых фациях увеличено значение магния, освободившегося 
при растворении слюдистых минералов. Образование доломита здесь происходило, по всей вероятности, уже во время диагенеза.

3. Использование отношения $\mathrm{Ca} / \mathrm{Mg}$ в качестве фациального показателя требует весьма многосторонних литогенетических исследований. При изучении таких древних отложений, как например, венлокские, его использование ограниченно. Значения $\mathrm{Ca} / \mathrm{Mg}$ в первичных карбонатных отложениях уменьшаются в направлении открытого моря. Особенно низкими эти значения являются в глинистых фациях. Обратная картина наблюдается только в зоне карбонатных отложений при наличии лагунной фации в прибрежном районе.

4. Исследование связи между кальцием и магнием в разных типах пород и разрезах указывает на многочисленность литогенетических факторов накопления обоих компонентов, особенно на многочисленность источников магния. При дальнейшем исследовании вопроса следует обратить внимание на характер этой связи в однотипных отложениях разных фаций, а также на характер связи между кальцием и магнием, с одной стороны, и другими элементами - с другой.

\section{Л И Т Е Р А Т У Р А}

К альо Д. Л. (ред.) и др. 1970. Силур Эстонии. Таллин.

Р н о В А. Б. 1956. Химический состав и условия формирования палеозойских карбонатных толщ Русской платформы. Тр. Геол. ин-та АН СССР, вып. 4.

Э й н а с т о Р. Э. 1968. Фациальные и палеогеографические условия образования эвриптеровых доломитов (силур Прибалтики). Междунар. геол. конгр., XXIII сесс. Докл. советск. геологов, пробл. 8.

$\mathrm{C}$ hill ing a r G. V. 1960. Ca/Mg ratios of calcareous sediments as a function of depth and distance from shore. Compass, 37.

In g e r s o n E. 1962. Problems of geochemistry of sedimentary carbonate rocks. Geochim. et Cosmochim. Acta, 26.

Ving is a a r P., Oraspōld A., E in a s to R., Jürgens on E. 1965. Karbonaatkivimite ühtne klassifikatsioon ja legend. ENSV TA Geol. Inst. Tallinn.
Институт геологии
Академии наук Эстонской ССР
Поступила в редакцию
$11 / \mathrm{I} 1973$

\section{ERIKA JORGENSON}

\section{CaO JA MgO JAOTUS BALTIKUMI UENLOKI SETTEIS}

Uenloki setete lahustuva osa analüüs näitab kaltsiumi- ja magneesiumisisalduses küllalt suurt vaheldust (tab. 1, joon. 1,2). Kaltsium, mis valdavalt esineb kaltsiidina, on suuremal hulgal levinud basseini ääreala setteis, eriti uenloki ülemistes kihtides (joon. 3). Magneesium esineb dolomiidina ja on levinud laialdaselt Ida-Baltikumi sekundaarse dolomiidistumise aladel uenloki ülemistes kihtides (joon. 4), samuti esineb dolomiiti mōnevõrra rohkem savikates setetes. $\mathrm{Ca} / \mathrm{Mg}$ kasutamine paleogeograafilistel rekonstruktsioonidel on küllalt keerukas, eriti kui arvestada setteis toimunud sekundaarseid muutusi. Kui karbonaatsete setete leviku alal on kõige rannalähedasema faatsiesena säilinud riffi faatsies (uenloki basseini loodeosas), väheneb $\mathrm{Ca} / \mathrm{Mg}$ pidevalt avamereliste savisetete suunas (joon. 6). Kui aga rannalähedasel alal esineb laguunne faatsies primaarsete dolomiitidega (Baltikumi kaguosa), on muutuste pilt vastupidine, kusjuures $\mathrm{Ca} / \mathrm{Mg}$ suurenemine jätkub, kuni hakkavad domineerima merglid ja domeriidid. Sealt peale algab uus vähenemine, mis saavutab miniumi savisetteis. Kaltsiumi ja magneesiumi vahelise korrelatsiooni uurimine näitab (tab. 3 , joon. 7 ), et köikides lubjakivides ühe elemendi hulga suurenedes teine kahaneb. Savides on mōlemad elemendid positiivses korrelatsioonis. Dolomiitides ja domeriitides on kahe elemendi vaheline korrelatsioon ebastabiilne. 


\section{ERIKA JORGENSON \\ CaO AND MgO DISTRIBUTION IN THE DEPOSITS OF THE BALTIC WENLOCKIAN}

Chemical analyses of the Wenlockian deposits show a great variance in calcium and magnesium content (Table 1, Figs $1-2$ ). The abundance of calcium, mainly represented by calcite, increases in the near-shore deposits of the upper part of the Wenlockian (Fig. 3). Magnesium, represented by mineral dolomite, is concentrated mainly in the secondary dolomites of the upper part of the Wenlockian in the East Baltic (Fig. 4). A notable conteint of dolomite has been established in the deep water clays, too. The use of $\mathrm{Ca} / \mathrm{Mg}$ ratio as a paleogeographic indicator is limited, especially in the cases of secondary alterations of the deposits, as it occurs in the Eastern Baltic. If the near-shore deposits are represented by reef-facies (North-Western part of the basin, see Fig. 6) the Ca/Mg ratio decreases constantly towards the deep water deposits. In the case of lagoon-facies (in the SouthEastern part of the basin) the $\mathrm{Ca} / \mathrm{Mg}$ ratio increases towards the off-shore until there appears the zone of marls and domerites. Beginning with the last it starts to decrease to a minimum in the clay deposits. The relationship between the content of calcium and magnesium differs in different rocks. The study of correlation coefficient shows (Table 3, Fig. 7) an inversely proportional relation between $\mathrm{Ca}^{*}$ and $\mathrm{Mg}^{*}$ in limestones, and a proportional relation in clays. In dolomites the relationship is of more unstable character. 